\title{
NUTRIENT, PHYTOCHEMICAL AND ANTI- NUTRIENT EVALUATION OF JATROPHA TANJORENSIS LEAF (HOSPITAL TOO FAR)
}

\author{
C.N. Nwachukwu \\ Department of Food Science and Technology, Imo State University, Owerri \\ *Corresponding Author: $\quad$ kizacar2003@gmail.com +2348038747878.
}

\begin{abstract}
The study investigated the nutrient, phytochemical and anti- nutrient composition of Jatropha tanjorensis leaf (Hospital Too Far). Samples were subjected to proximate composition, mineral, vitamin, phytochemical and anti-nutrient contents analyses. The moisture, ash, crude fat, crude fibre, protein and carbohydrate contents were $81.62 \%, 0.98 \%, 4.90 \%, 2.80 \%, 5.37 \%$ and $4.33 \%$ respectively. Data obtained for mineral composition showed that magnesium, calcium, sodium, potassium, phosphorus, iron and zinc contents were $32.81 \mathrm{mg} / 100 \mathrm{~g}, 36.85 \mathrm{mg} / 100 \mathrm{~g}, 19.89 \mathrm{mg} / 100 \mathrm{~g}$, $43.15 \mathrm{mg} / 100 \mathrm{~g}, 4.28 \mathrm{mg} / 100 \mathrm{~g}, 9.95 \mathrm{mg} / 100 \mathrm{~g}$ and $14.49 \mathrm{mg} / 100 \mathrm{~g}$ respectively. Data obtained for vitamin composition showed that vitamin $B_{1}$, vitamin $B_{2}$, vitamin $B_{3}$ and vitamin $C$ were $2.46 \mathrm{mg} / 100 \mathrm{~g}, 1.03 \mathrm{mg} / 100 \mathrm{~g}, 3.18 \mathrm{mg} / 100 \mathrm{~g}$ and $26.41 \mathrm{mg} / 100 \mathrm{~g}$ respectively. Data obtained for antinutrient and phytochemical profiles showed that tannin, saponin, flavoniod, phytate, alkaloid and hydrogen cynaide contents were $1.23 \mathrm{mg} / 100 \mathrm{~g}, 3.91 \mathrm{mg} / 100 \mathrm{~g}, 3.35 \mathrm{mg} / 100 \mathrm{~g}, 0.22 \mathrm{mg} / 100 \mathrm{~g}$, $1.92 \mathrm{mg} / 100 \mathrm{~g}$ and $0.88 \mathrm{mg} / 100 \mathrm{~g}$ respectively. The proximate, mineral elements, vitamin, antinutrient and phytochemical profiles results obtained from the analyses of Jatropha tanjorensis leaf indicated that Jatropha tanjorensis leaf may be recommended for human consumption and the consumption of this vegetable in adequate amount could contribute immensely towards meeting human nutritional need for normal body growth and adequate protection against diseases caused by malnutrition.
\end{abstract}

Key words: Jatropha tanjorensis leaf, nutrients, anti-nutrients, phytochemical.

https://dx.doi.org/10.4314/jafs.v16i2.4

\section{INTRODUCTION}

Jatropha tanjorensis is genus of flowering plants in the spurge family Euphorbiaceae. It is a native of Central America and has become naturalized in some tropical and subtropical countries like India, Nigeria and Canada (Anwar, 2007). Jatropha tanjorensis is a natural hybrid between Jatropha curcas and Jatropha grossypifolia (Anwar, 2007). Jatropha tanjorensis is a shrub $6 \mathrm{~m}$ high with spreading branches off stubby twinges and smooth gray bark which gives off whitest coloured latex when cut. The leaves are delicious alternate but with apical crowded, acute to alternate basally cordate $3-5$ lobe in outline, $6-40 \mathrm{~cm}$ broad the petioles $3-8 \mathrm{~cm}$ long (Madubuike et al., 2015).

It is a common weed of field crops, bush re-growth, road side and disturbed places in higher rainfall forest zone of West Africa. It is commonly called hospital too far, catholic vegetable, ugu-oyibo, 
iyana-Ipaja, lapalapa. Its primarily used for fencing while its secondary uses are as a source of edible leafy vegetable and as a medicine (Igbinaduwa et al., 2011).

It is a multipurpose plant, cultivated for medicinal applications and used as food. Virtually every part of the plant is beneficial and nutritional in various ways. Its many benefits depend on which part of the plant is being used. The leaves are commonly cooked and eaten like vegetables such as fluted pumpkin leaves (Ugu) and spinach (Anwar, 2007).

Jatropha tanjorensis possesses significant anticancer, hepatoprotective and pesticidial activity (Anwar, 2007). The stem sap stops bleeding and itching of cuts and scratches. The root decoction is used as a mouth wash for treating bleeding gums, toothache, eczema, ringworm and scabies and also treat dysentery and venereal diseases (Locket et al., 2000). The leaf extract is consumed as a blood tonic with the claim that it increases blood volume. It can also be used as an alternative to lettuce in salad preparation amongst other very vital usages as reported by many authors (Igbinaduwaet al., 2011). The local people of Alagorinha, Perambuco and Northeast Brazil use the latex from Jatropha tanjorensis for external application and the consumption of latex by diluting it with water has been claimed to treat snake poisoning (Albuquerque et al., 2006).

The oxidant potential of the leaf extract has been investigated and was discovered to have antioxidative potential against reactive oxygen species produced in protein energy malnutrition (Omoregie and Osagie, 2011). The seed oil of Jatropha tanjorensis is used for the treatment of rheumatism and paralytic affections (Omorgie and Osagie, 2011). The root is used by traditional medicine practitioners in the treatment of sexually transmitted infections and urinary tract infections. It is also used to treat menstrual pains, irregular periods and to ensure a strong foetus during pregnancy (Van Wyk, 2005).

Despite the great potentials of Jatropha tanjorensis as a medicinal leaf, it has not found a wide application in food systems. Its usage has mostly been localized due to lack of scientific information on Jatropha tanjorensis and its nutrient as well as anti-nutrient content. This study therefore is aimed at evaluating the nutrient, phytochemical and anti- nutrient composition of Jatropha tanjorensis leaf (Hospital Too Far).

\section{MATERIALS AND METHODS}

\section{Sample Collection and Preparation}

Jatropha tanjorersis leaves were harvested from a local farm in Ahiazu Mbaise L.G.A of Imo State and identified in the Department of Crop Science and Biotechnology of Imo State University, Owerri.Fresh leaves of Jatropha tanjorensis were harvested, sorted and washed with clean water to remove dirts and unwanted materials that may be adhering on the leaves and after washing, the samples were air dried and taken to the laboratory for analyses.

\section{Analyses}

\section{Determination of Proximate Composition}

The moisture, protein, fat, ash and crude fibre contents of the leaves sample were carried out according to the methods of AOAC (2010) while carbohydrate was calculated by differences. 


\section{Determination of Minerals}

Calcium, magnesium, phosphorus, sodium and potassium contents of the sample were determined using the methods described by James (1995). Zinc content and iron content were determined using the method of AOAC (2010).

\section{Determination of Vitamins}

Ascorbic acid, niacin, thiamin and riboflavin contents of the sample were determined using the methods described by Onwuka (2005).

\section{Determination of Anti Nutrients and Phytochemicals}

Tannin and phytate contents were determined using the methods described by Onwuka (2005) while saponin, flavonoid and alkaloid contents were determined using the methods described by Harbone (1992).

\section{Statistical Analyses}

All data obtained were expressed as the mean \pm SD of three observations.

\section{RESULTS AND DISCUSSION}

\section{Proximate Composition of the Jatropha tanjorensis Leaf Sample}

The result of the proximate composition of the Jatropha tanjorensis leaf sample is presented in Table 1. The result revealed that the moisture content of the Jatropha tanjorensis leaf sample is $81.62 \%$. Result obtained in this present study was found to be similar to the report of Olaiya and Adebisi (2010) who recorded a moisture content of $75.00 \%$ in S. aethiopicum and $91.5 \%$ in $T$. traingulare. As indicated in Table 1, the moisture contents obtained from the Jatropha tanjorensisleaf sample was high. This may be due to the state of freshness of the leaf. The high moisture content in green vegetables provides part of the medium for normal functioning of enzymes and general metabolic processes (Iyaka et al., 2014). The high moisture content of vegetables makes them to aid the digestion of food (Olaiya and Adebisi, 2010).

It was observed that the ash content for the Jatropha tanjorensis leaf sample was low $(0.98 \%)$ when compared to $11.17 \pm 1.2$ obtained for Brassica oleracea (cabbage) leaves by (Iyaka et al., 2014) but compared favourably with the value of $0.94 \%$ recorded for Amaranth by Olumakaiye (2011). Samples with high percentages of ash contents are expected to have high concentrations of various mineral elements, which are expected to speed up metabolic processes and improve growth and development (Bello et al., 2008).

The fat content of the Jatropha tanjorensis leaf sample was found to be $4.90 \%$. The value obtained in this present study conforms to the range of $1.60 \%$ to $4.15 \%$ indicated by Iheanacho and Udebuani (2009) for nutritional composition of some leafy vegetables consumed in Imo State. The low values obtained is in agreement with the general observation that leafy vegetables are low lipid containing foods that play significant role in avoiding obesity (Lintas, 1992).

The mean fibre content obtained was is comparable to the $3.16 \%$ reported by Iheanacho and Udebuani (2009) for Curcubita pepo. Lower values have been reported for Telfairia occidentalis 
leaves by Iyaka et al. (2014). The result obtained also indicates that the Jatropha tanjorensis leaf sample analyzed could be a source of dietary fiber with nutritional benefits.

It was observed that the Jatropha tanjorensis leaf sample analyzed had protein contents comparatively higher when compared to $3.33 \%$ indicated for the leaves of Ocimum gratissimum (Islam et al., 2004) and 3.16\% for Amaranth leaves (Olumakaiye, 2011). The relatively high $(5.37 \%)$ protein content of the Jatropha tanjorensis leaf made it an important source of protein that can be used to complement other sources of protein. Proteins are essential component of diet needed for survival of animals and human beings whose basic function is to supply adequate amounts of required amino acids for nutrition (Pugalenthal et al., 2004).

It was indicated that the carbohydrate content of the Jatropha tanjorensis leaf sample analyzed was relatively low (4.33\%). Main function of carbohydrate in the body is for energy supply. Ifon and Bassir (2007) noted that leafy vegetables may not be an important sources of carbohydrates hence their consumption along with other carbohydrate rich food such as cereals.

\section{Mineral Composition of the Jatropha tanjorensis Leaf Sample}

The result of the mineral composition of the Jatropha tanjorensisleaf sample is presented in Table 2. Magnesium value obtained in Jatropha tanjorensis leaf was found to be higher $(32.81 \mathrm{mg} / 100 \mathrm{~g})$ than the $1.53 \mathrm{mg} / 100 \mathrm{~g}$ reported by Kamga et al. (2013) for African eggplant (Solanum aethiopicum) commonly cultivated in the South-Eastern Nigeria. Based on the result obtained, Jatropha tanjorensis leaf might contribute adequate magnesium to the daily need. Magnesium is needed for more than 300 biochemical reactions in the body. It helps maintain muscle and nerve functions, keeps heart rhythm steady and supports a healthy immune blood and regulates blood sugar levels (Saris et al., 2000).

The calcium and phosphorus contents of the Jatropha tanjorensis leaf sample were indicated as $36.85 \mathrm{mg} / 100 \mathrm{~g}$ and $4.28 \mathrm{mg} / 100 \mathrm{~g}$ respectively. Food is considered "good" if $\mathrm{Ca} / \mathrm{P}$ ratio is above one and "poor" if the ratio is less than 0.5 , while the $\mathrm{Ca} / \mathrm{P}$ ratio above two helps to increase the absorption of calcium in the intestine (NRC, 1989). The $\mathrm{Ca} / \mathrm{P}$ ratios of Jatropha tanjorensisleaf sample analyzed was above the recommended value of 1.00. Calcium plays an important role in building strong as well as in the keeping of healthy bones and teeth at both early and later life. The sodium and potassium contents of the Jatropha tanjorensis leaf sample were found to be $19.89 \mathrm{mg} / 100 \mathrm{~g}$ and $43.15 \mathrm{mg} / 100 \mathrm{~g}$ respectively. The sodium to potassium ratio in the body is of great concern for the prevention of hypertension (Alinnor and Akalezi, 2010; Zhang et al., 2013).

According to the World Health Organization (2002), the sodium-to-potassium ratio should be $\leq$ one. This implies that the consumption of Jatropha tanjorensis leaf would promote normal functioning of nervous system and prevent high blood pressure.

Sodium plays a significant role in the blood plasma and normal functioning of nervous system while potassium is an essential element in the body system that plays a vital role in protein synthesis, nerve conduction; control of heart beat, muscle contraction and synthesis of nucleic acids (Saris et al., 2000).

The iron level $(9.95 \mathrm{mg} / 100 \mathrm{~g})$ in the Jatropha tanjorensis leaf analyzed which is close to the $18 \mathrm{mg} / 100 \mathrm{~g}$ recommended daily allowances for adults as describe by WHO/FAO (1991), makes it a potential source of iron for vulnerable groups such as children under five and pregnant and lactating women. Iron deficiency anaemia is responsible for $20 \%$ of neonatal mortality and $10 \%$ of maternal 
mortality, or about 800,000 deaths, representing $2.4 \%$ of annual global deaths from disease (Saris et al., 2000). The consumption of Jatropha tanjorensis leaf can thus help reduce the mortality due to anaemia among pregnant women and children in developing countries.

The zinc content value $(14.49 \mathrm{mg} / 100 \mathrm{~g})$ recorded in this present study was found to be higher compared to the $(0.80$ to $2.05 \mathrm{mg}$ and 3.00 and $23.00 \mathrm{mg} / 100 \mathrm{~g})$ range observed for some indigenous vegetables respectively as reported by Okafor et al. (1998). Promoting cultivation and consumption of Jatropha tanjorensis leaf which contains appreciable amount of zinc will help to alleviate health problems associated with zinc deficiency.

\section{Vitamin Composition of the Jatropha tanjorensis Leaf Sample}

The result of the vitamin composition of the Jatropha tanjorensis leaf sample is presented in Table 3. As vitamins cannot be synthesized in the human body, they must be supplied constantly by food. It was observed that the Jatropha tanjorensis leaf sample analyzed contained appreciable $(26.41 \mathrm{mg} / 100 \mathrm{~g})$ quantity of vitamin C.

Vitamin $\mathrm{C}$ activates the functions of all the cells. It is a powerful antioxidant. It favours the absorption of iron in the intestines, protects against infections and intervenes in the healing of wounds. Vitamin $\mathrm{C}$ also maintains blood vessels flexibility and improves circulation in the arteries of people including smokers (Igwe et al., 2011).

The niacin (Vitamin $\mathrm{B}_{3}$ ) content value $(3.18 \mathrm{mg} / 100 \mathrm{~g}$ ) obtained was found to agree with the report of Pandey et al. (2006) for leafy vegetable paratha. The primary health benefit of niacin is a significant decrease in heart disease. It helps lower the level of bad cholesterol. This implied that consumption of Jatropha tanjorensis leaf will be of great health benefits.

It was indicated that Jatropha tanjorensis leaf contained appreciable $(2.46 \mathrm{mg} / 100 \mathrm{~g})$ quantity of Thiamine (vitamin $B_{1}$ ) and met the $0.3-0.4 \mathrm{mg} / 100 \mathrm{~g}$ RDA for vitamin $\mathrm{B}_{1}$. Thiamine is one of the water soluble vitamins that play important role in diets. It is well known to help in energy production as well as in good function of the central nervous system (Igwe et al., 2011).

The riboflavin (vitamin $\mathrm{B}_{2}$ ) content $(1.03 \mathrm{mg} / 100 \mathrm{~g})$ of Jatropha tanjoensis leaf fell within the 0.4 $0.5 \mathrm{mg} / 100 \mathrm{~g}$ RDA for vitamin $\mathrm{B}_{2}$. This implied that consumption of Jatropha tanjorensis leaf will supply the body with sufficient vitamin $\mathbf{B}_{2}$. Riboflavin (vitamin $\mathrm{B}_{2}$ ) is a vitamin that works as coenzyme in many physiological reactions in the boiling process. It is also associated with conversion of amino acid, tryptophan to niacin.

\section{Anti-Nutritient Composition of the Jatropha tanjorensis Leaf Sample}

The result of the anti-nutrient composition of the Jatropha tanjorensis leaf sample is presented in Table 4. The value obtained for phytate $(0.22 \mathrm{mg} / 100 \mathrm{~g})$ did not exceed the safe limit as recommended by Onimawo and Akubor (2012). According to Onimawo and Akubor (2012), ingestion of $2.5 \mathrm{~g}$ or more of phytic acid per day has been reported to cause reduction in bioavailability of calcium, iron and zinc. Phytates limit the availability of some notable minerals like magnesium, iron, and even calcium. Phytic acid has also been implicated in the removal of phosphorus and causing indigestion and flatulence in human system (Groff et al., 1995).

The hydrogen cyanide content of the Jatropha tanjorensis leaf sample was $0.88 \mathrm{mg} / 100 \mathrm{~g}$. Hydrogen cyanide is toxic and can be dangerous at high concentrations. Onwuka (2005) reported $50 \mathrm{mg} / \mathrm{kg}$ as a critical concentration of the toxic substance in foods 


\section{Phytochemical Composition of the Jatropha tanjorensis Leaf Sample}

The result of the phytochemical composition of the Jatropha tanjorensis leaf sample is presented in Table 5. The tannin content of the Jatropha tanjorensis leaf sample was $1.23 \mathrm{mg} / 100 \mathrm{~g}$. Tannins have antioxidant effects which help in cancer prevention (Ujonwundu et al., 2010). According to WHO (2002), tannin level in foods below $5 \mathrm{mg} / 100 \mathrm{~g}$ are safe for human consumption. The Jatropha tanjoensis leaf sample had tannin content below $5 \mathrm{mg} / 100 \mathrm{~g}$ and implied that the antioxidant effects will help in cancer prevention.

The saponin content of the Jatropha tanjorensis leaf sample was $3.91 \mathrm{mg} / 100 \mathrm{~g}$. High level of saponin has been associated with gastroenteritis manifested by diarrhoea and dysentery (Gernah et al., 2007), acute poisoning is relatively rare (Awe and Sodipo, 2001) although these toxic principles exhibit useful medicinal properties (Afiukwa and Igwe, 2015). So their presence in the Jatropha tanjorensis leaf is a pointer to the medicinal value of the food material. Some general properties of saponins include formation of foams in aqueous solution, hemolytic activity and cholesterol binding properties and bitterness (Sodipo et al., 2000). Saponins' anti-microbial activities make them good for treating fungal and yeast infections (Okwu and Ndu, 2006).

The flavonoid content of the Jatropha tanjorensis leaf sample was $3.35 \mathrm{mg} / 100 \mathrm{~g}$. Flavonoids are potent water-soluble super antioxidants and free radical scavengers. However, moderate intake of flavonoid is essential for normal heart beat, neuromuscular and metabolic activities (Onimawo and Akubor, 2012). Flavonoid also prevents oxidative cell damage, have strong anticancer activity and protect against all stages of carcinogenesis (Bello et al., 2008).

The alkaloid content of the Jatropha tanjorensis leaf sample was $1.92 \mathrm{mg} / 100 \mathrm{~g}$. Alkaloids are important therapeutically and significantly plant secondary metabolites. Isolated pure form of alkaloids and their synthetic derivatives are used as basic medicinal agents for their analgesic and bactericidal effects (Morton, 2001).

\section{CONCLUSION}

The proximate composition, mineral elements, vitamin, anti-nutrient and phytochemical profiles results obtained from the analyses of Jatropha tanjorensis leaf indicated that consumption of this vegetables in adequate amount could contribute immensely towards meeting human nutritional need for normal body growth and adequate protection against diseases caused by malnutrition. High potassium content was recorded in the leaf sample which made it useful for hypertensive patient since potassium reduces high blood pressure.

Jatropha tanjorensis leaf containing appreciable iron and vitamin $\mathrm{C}$ contents made it an asset for people with low red blood cell count because vitamin $\mathrm{C}$ promotes iron absorption from the small intestine which helps in checkmating anemia. Consumption of Jatropha tanjorensis leaf will help solve this problem of anemia. Increasing the cultivation and consumption of Jatropha tanjorensis leaves will help ensure low-cost nutrients reach vulnerable populations and enhance food and nutritional security. 


\section{REFERENCES}

Afiukwa A.C. and Igwe O.D. (2015). Nutritional and phyto chemical evaluation of the aerial and underground tubers of air potato. British Journal of Applied Science and Technology (11): 2231- 2248.

Albuquerque, U.P., Monteiroa, J.M., Ramosa, M.A. and de Amorim, E.L. (2006). Medicinal and magic plants from a public market in Northeastern Brazil. $J$. Ethnopharmacol ;; 110: 76-91.

Alinnor, J. I. and Akalezi C.O. (2010). Proximate and mineral composition of Diuscorea rotundata (white yam) and Colocasia esculariata (white cocoyam). Pak J. Nutr. 9 (10): 998-1001

Anwar, F. (2007). "A food plant with multiple medicinal uses. Journal of Food Sciences and Nutrition; 21:17-25.

AOAC (2010). Official methods of Analysis (18 ${ }^{\text {th }}$ Ed.) Association of Official Analytical Chemists, Washington D.C.

Awe, I. S. and Sodipo, O. A. (2001).Studies on the chemical composition and physio-chemical properties of seeds of some wild plants. Nigerian Journal of Food Science and Nutrition. 3: 103-107.

Bello, B.C., Izergina, N., Cavssinus, E. and Reicjert, H. (2008). Amplification of neutral stem cell. Proliferative By Intermediate Progenitor Cells in Drosophila Brain Development. Neural Dev. 19(3):5.

Gernah D.I., Atolagbe, M.O. and Echegwo, C.C. (2007). Nutritional composition of the African locust bean. Biger Food J. 25(1): 190-196.

Groff, J., Gropper, S. and Hunt, S. (1995). Advanced Nutritional and Human Metabolism. 2nd edn., New York. 221- 362.

Harbone, J.B. (1992). Photochemical methods: A Guide to Modern Techniques of Plants Analysis. Chaman and Hall Ltd, London. 279.

Ifon, E.T. and Bassir, O. (2007). The nutritive value of some Nigerian leafy green vegetables. Journal of Food Chemistry. 1: 231-235.

Igbinaduwa, P.O., Usifoh, C.O. and Ugwu, C.C. (2011). Phytochemical analysis and toxicological evaluation of the methanol extract of Jatropha tanjorensis leaf. J Pharm. Biores; 8: 86-91.

Igwe, C.U, Ujowundu, C.O., Nwaogu, L.A. and Okwu, G.N. (2011) Chemical analysis of an edible African termite, Macrotermes nigeriasis: A Potential Antidote to Food Security Problem. Biochem and Anal Biolochem;1:(105): 1009- 2161.

Iheanacho, K. M. and Udebuani, A. C. (2009). Nutritional Composition of Some Leafy Vegetables Consumed in Imo State, Nigeria.Appl. Sci. Environ. Manage. 13(3) 35 - 38.

Islam, M. D., Rezuanul, D. K. and Shaha, R. K. (2004). Nutritional importance of some leafy vegetables in Bangladesh. Pakistan Journal of Biological Sciences. 7(8): 1380- 1384. 
Iyaka Y.A. (2014). Concentration of calcium and zinc in some fruits and vegetables commonly available in North-Central zone of Nigeria. Journal of Environmental, Agricultural and Food Chemistry; 6(6); 2150-2154.

James, C. S. (1995). Analytical chemistry of foods. Blackie Academic and Professional: Glasgow, UK. pp. 71- 91.

Lintas, C. (1992). Nutritional aspects of fruits and vegetables consumption. Options Mediterraeennes. 19: 79- 87.

Lockett, C.T., Calvert, C.C. and Grivetti, L.E. (2000). Energy and micronutrient composition of dietary and medicinal wild plants consumed during drought. Study of rural Fulani, Northeastern Nigeria. International Journal of Food Science and Nutrition; 51: 195- 208.

Madubuike, K.G., Yusuf, N.O. and Robinson, E.S. (2015). Evaluation of the in vitro and in vivo antioxidant potentials of Jatropha tanjorensis methanol leaf extract. Internal J. Pharm. Phytochem. Res.; 7: 43-51.

Morton, J. (2001). Purple mombin fruits of warm climates. Miami Publishers: New York, p.245

National Research Council (NRC) (1989). Recommended Dietary Allowance $10^{\text {th }}$ ed National Academic press Washington DC, USA.

Okwu, D.E. and Ndu, C.U. (2006) Evaluation of the phytonutrients Mineral and Vitamin Contents of some Varieties of yam (Dioscorea spp.). International Journal of Molecular Medicine and Advance Science, 2:199-203.

Olaiya, C. and Adebisi, J. (2010). Phytoevaluation of the nutritional values of ten green leafy vegetables in South-Western Nigeria. The Internet Journal of Nutrition and wellness. 9(2): 192- 198.

Olumakaiye, M. F. (2011). Evaluation of nutrient contents of amaranth leaves prepared using different cooking methods. Food and Nutrition Science; (2): 249- 252.

Omoregie, E.S. and Osagie, A.U. (2011). Effect of Jatropha tanjorensis leaves supplement on the activities of some antioxidant enzymes, vitamins and lipid peroxidation in rats. J. food Biochem. 35(2): 409- 424.

Onimawo I.A. and Akubor P.1. (2012) Food chemistry (Integrated Approach with biochemical background). $2^{\text {nd }}$ Edition, Joytal Printing Press, Agbowo, Ibadan Nigeria.

Onwuka, G. I. (2005). Food Analysis and Instrumentation: Theory and Practice. Naphtali Prints, Lagos. pp 156-161.

Pandey M., Abidi A.B., Singh S. and Singh R.P. (2006). Nutritional evaluation of leafy vegetable paratha. J. Hum. Ecol. (19): 155-156.

Pugalenthal, M., Vadivel, V., Gurumoorthi, P. and Janardhanam, K. (2004). Comparative nutritional evaluation of little known legumes Tamarandus indica, Erythrina indica, Sesbania bispinosaTrop. Subtrop. Agroecosyst; 4:107-123.

Saris N.E., Mervaala, E. and Karppanen, H. (2000). Clinical and analytical aspects. Clin. Chem.; 4 (2): $2641-46$. 
Sodiop O.A, Akiniyi J.A. and Ogunbamosu J.U (2000). Studies on certain characteristics of extracts of bark of Pansinystallia macrucucerias. Global J. Pure Appl. Sci. 6: 83-87.

Soetan K.O., Olaiya, C.O. and Oyewole, O.E. (2010). The importance of mineral elements for humans, domestic animals and plant. African Journal of food science; 4(5): 200- 222.

Ujonwundu, C.O., Okafor, O.E., Agha, N.C., Nwaogu, L.A., Igwe, K.O. and Igwe, C. U. (2010). Chemical composition of Combretum zenkeri leaves. Journal of Medicinal Plants Research; 4 (10): 965-968.

Van Wyk, W. M. (2005). Medicinal Plants of the World. Briza Pulications, Pretoria, South Africa. pp. 38- 349.

WHO (World Health Organization). (2002). The world health report 2002 - Reducing risks, promoting healthy life. Geneva, WHO.

Zhang, F., Cogswell, M.E., Gillespie, C., Fang, J., Loustalot, F. and Dai, S. (2013). Association between usual sodium and potassium intake and blood pressure and hypertension amongst adults. J. Acad. Nutr Diet.; 8(10): e75289. 
Table 1: Proximate Composition of the Jatropha tanjorensis Leaf Sample

\begin{tabular}{ll}
\hline Parameter & Composition $(\boldsymbol{\%})$ \\
\hline Moisture content & $81.62 \pm 0.14$ \\
Ash & $0.98 \pm 0.00$ \\
Crude fat & $4.90 \pm 0.14$ \\
Crude fiber & $2.80 \pm 0.14$ \\
Protein & $5.37 \pm 0.17$ \\
Carbohydrate & $4.33 \pm 0.04$ \\
\hline
\end{tabular}

Values are Mean \pm SD of duplicate determinations

Table 2: Mineral Composition of the Jatropha tanjorensis Leaf Sample

\begin{tabular}{lc}
\hline Parameter & Composition $(\mathbf{m g} / \mathbf{1 0 0 g})$ \\
\hline Magnesium & $32.81 \pm 0.12$ \\
Calcium & $36.85 \pm 0.00$ \\
Sodium & $19.89 \pm 0.04$ \\
Potassium & $43.15 \pm 0.09$ \\
Phosphorus & $4.28 \pm 0.00$ \\
Iron & $9.95 \pm 0.29$ \\
Zinc & $14.49 \pm 0.00$ \\
\hline
\end{tabular}

Values are Mean \pm SD of duplicate determinations

Table 3: $\quad$ Vitamin Composition of the Jatropha Tanjorensis Leaf Sample

Parameter

Vitamin C

Niacin (vitamin $\mathrm{B}_{3}$ )

Thiamine (vitamin $\mathrm{B}_{1}$ )

Riboflavin (vitamin $\mathrm{B}_{2}$ )

Values are Mean \pm SD of duplicate determinations
Composition (mg/100g)

$$
\begin{aligned}
& 26.41 \pm 0.05 \\
& 3.18 \pm 0.00 \\
& 2.46 \pm 0.00 \\
& 1.03 \pm 0.09
\end{aligned}
$$


Table 4: Anti-Nutrient Composition the Jatropha tanjorensis Leaf Sample

\begin{tabular}{ll}
\hline Parameter & Composition $(\mathrm{mg} / 100 \mathrm{~g})$ \\
\hline Phytate & $0.22 \pm 0.00$ \\
Hydrogen cyanide & $0.88 \pm 0.11$ \\
\hline
\end{tabular}

Values are Mean \pm SD of duplicate determinations

Table 5: Phytochemical Composition the Jatropha tanjorensis Leaf Sample

\begin{tabular}{cc}
\hline Parameter & Composition $(\mathrm{mg} / 100 \mathrm{~g})$ \\
\hline Tannin & $1.23 \pm 0.04$ \\
Saponin & $3.91 \pm 0.13$ \\
Flavonoid & $3.35 \pm 0.21$ \\
Alkaloid & $1.92 \pm 0.19$ \\
\hline
\end{tabular}

Values are Mean \pm SD of duplicate determinations 